\title{
ANALISIS PENGARUH BRAND ASSOCIATION, BRAND AWARENESS, PRICE, DAN ROLE MODEL TERHADAP PURCHASE INTENTION (STUDI PADA SEPATU FUTSAL NIKE CR7)
}

\author{
Dimas Ilham Nur Rois, Aji Yudha, Yuli Rika Riftian \\ Fakultas Ekonomi, Unversitas Islam Surakarta \\ Email : dimasilham94@gmail.com
}

\begin{abstract}
Abstrak : Penelitian ini bertujuan untuk mengetahui pengaruh Brand Association, Brand Awareness, Price, dan Role Model terhadap Purchase Intention Studi Pada Sepatu Futsal Nike CR7. Penelitian ini menggunakan kuesioner dalam pengambilan data primer dan pendekatan kuantitatif dengan analisis Regresi Linier Berganda. Populasi dalam penelitian ini adalah konsumen yang berdomisili di Kota Surakarta. Pengambilan sampel menggunakan teknik Convenience Samping. Hasil dari penelitian ini menunjukkan bahwa Brand Association dan Brand Awereness tidak berpengaruh terhadap Purchase Intention sedangkan Price dan Role Model berpengaruh terhadap Purchase Intention.
\end{abstract}

Kata Kunci : Brand Association, Brand Awareness, Price, Role Model dan Purchase Intention

\section{PENDAHULUAN}

Keputusan konsumen dalam membeli dapat diartikan sebagai membeli dalam jumlah sedikit, atau membeli dalam jumlah yang besar atas suatu produk atau jasa. Hal ini dapat disebabkan oleh banyak pertimbangan yang mempengaruhi konsumen untuk membeli. Pertimbangan tersebut dapat berupa tingkat pengetahuan konsumen, pemahaman konsumen tentang produk atau jasa, dan pengalaman menggunakan produk atau jasa sebelumnya (Nitisusastro, 2012).

Schiffman dan Kanuk (2000) membagi pertimbangan konsumen dalam membeli produk. Pertama, Pertimbangan Ekonomis (An Economic View) yaitu tipikal pertimbangan secara ekonomis terkait dengan perhitungan konsumen secara ekonomis atas barang atau jasa yang akan dibeli. Konsumen akan menimbang antara manfaat yang diperoleh dengan pengorbanan yang dilakukan. Kedua, pertimbangan pasif (A Passive View) yaitu tipikal konsumen dimana mereka tidak berfikir secara rasional dan sangat dipengaruhi oleh factor - factor internal yang melekat pada induvidu setiap konsumen. Faktor - factor tersebut meliputi persepsi, kepribadian, pembelajaran, motivasi, dan sikap.

Harga suatu barang merupakan factor rasional yang dapat dijadikan ukuran konsumen tersebut memutuskan membeli atau tidak. Harga merupakan alat yang sangat berguna dalam mengukur kualitas produk yang dimiliki (Hunt dan Mello, 2015). Penetapan harga ini sering dikatikan dengan value yang dimiliki oleh suatu produk. Value bisa diartikan sebagai benefit yang konsumen dapatkan ketika menggunakan produk tersebut (Hunt et. al, 2015). Oleh karena itu, penetapan harga akan sangat mempengaruhi keputusan pembelian oleh konsumen. Wowor dan Lunarjanto (2014) menjelaskan bahwa harga mempengaruhi konsumen untuk membeli tiket pesawat Garuda Indonesia.

Brand diartikan sebagai nama, symbol, atau desain yang menjadi identitas dan pembeda suatu produk (Hunt, et. al, 2015).Suatu brand yang kuat akan mudah diingat oleh konsumen sehingga akan mempengaruhi konsumen dalam membeli produk. Hal tersebut dapat terjadi karena adanya brand equity dimana konsumen akan mempersepsikan secara positif brand tersebut. Brand equity dapat diukur melalui brand association dan brand awareness. Brand 
association menggambarkan pemikiran konsumen tentang suatu brand (Tjiptono, 2005). Sedangkan brand awareness menggambarkan seberapa jauh brand tersebut dikenali oleh konsumen (Kotler, 2006). Wowor dkk., (2014) menjelaskan bahwa Brand Awareness dan Brand Association berpengaruh pada keputusan membeli tiket maskapai Garuda Indonesia.

Perusahaan yang ingin membentuk suatu brand yang positif juga sering menggunakan role model yang disandingkan dalam suatu produk. Role model dapat berupa artis, sportsman, atau politisi yang disesuaikan dengan apa yang ingin disampaikan kepada konsumen. Hal ini akan mempermudah konsumen dalam mengingat suatu brand dan menciptakan trend baru. Penggunaan selebriti juga meningkatkan niat beli bagi konsumen apabila konsumen tersebut juga mengidolakannya. Run, Butt, Nee (2010) menyimpulkan dalam penelitiannya terhadap siswa di Malaysia bahwa perilaku artis sebagai role model mereka berdampak pada tingkah laku responden.

Penelitian ini mengkonstruksikan model yang dikembangkan oleh Wowor dan Lunarjanto (2014) yang mengemukakan bahwa brand equity dan pricing berpengaruh terhadap Purchase Intention. Penelitian yang dilakukan oleh Wowor dan Lunarjanto (2014) tidak memasukkan role model namun Haroon, Haq, Najmo (2015) mengemukakan dalam temuannya bahwa salah satu factor pembentuk purchase intention adalah role model. Penelitian ini memilih obyek sepatu futsal Nike CR7. Pemilihan ini dikarenakan sepatu futsal sering menggunakan role model dalam mempromosikan produknya dan memiliki range harga yang menengah dimana konsumen berpikir terlebih dahulu sebelum membeli.

Berdasarkan penelian diatas, maka peneliti mengajukan sebuah penelitian yang berjudul: Brand Association, Brand Awareness, Price dan Role Model Terhadap Purchase Intention (Studi Pada Konsumen Produk Sepatu Futsal Nike CR7 di Eks Karisidenan Surakarta).

\section{KAJIAN TEORI}

\section{Self-Concept Theory}

Self - Concept Theory menyatakan bahwa induvidu memiliki konsep tentang siapa mereka (actual self) dan idola mereka (ideal self). Self concept theory ditentukan 2 prinsip: keinginan untuk mendapatkan self - consistency dan keinginan untuk meningkatkan self- esteem (Assael, 1998). Self concept theory menjelaskan bagaimana konsumen dapat tertarik untuk membeli produk bukan hanya berdasarkan pada apa yang mereka butuhkan, namun lebih kepada bagaimana emosi mempengaruhi mereka untuk membeli suatu produk.

\section{Purchase Intention}

Purchase intention menunjukkan seberapa besar keinginan konsumen membeli suatu merek atau seberapa besar kemungkinan konsumen untuk berpindah dari satu merek ke merek lainnya (Kotler, 1998). Keinginan untuk membeli akan muncul apabila konsumen sudah mengevaluasi dan menganggap apa yang dibeli sudah sesuai dengan ekspektasinya. Konsumen yang berniat untuk membeli akan melakukan beberapa hal yang disebut dengan instrumental action yaitu serangkaian proses yang dilakukan oleh konsumen hingga mereka membeli produk (Assael, 1998).

\section{Brand Equity}

Brand equity didefinisikan sebagai perspektif positif dari konsumen atas suatu produk. Brand equity akan meningkatkan keinginan konsumen untuk membeli produk. Perusahaan yang menciptakan brand equity yang kuat akan berdampak positif karena konsumen akan mengingat suatu brand sehingga akan berdampak pada peningkatan market share sebuah perusahaan. Brand equity dikelompokkan menjadi lima kategori diantaranya adalah brand loyalty (loyalitas merek), 
brand awareness (kesadaran merek), perceived quality (persepsi kualitas), brand association (asosiasi merek), dan other proprietary brand assets (royalty, lisensi, dan lain - lain) (Aaker dalam Kotler, 2006).

\section{Brand Association}

Brand association merupakan persepsi merek atau brand dalam benak konsumen (Tjiptono, 2005). Lebih jauh, Aaker (1996) menjelaskan bahwa brand association merupakan cerminan pencitraan suatu merek terhadap kesan tertentu dalam kaitannya dengan kebiasaan, gaya hidup, manfaat, atribut produk, geografis, harga, pesaing, selebriti, dan lain - lain. Menurut Aaker dalam Durianto, 2001 Fungsi brand association yaitu membantu memproses atau menyusun informas, Membedakan atau memposisikan brand, Membangkitkan alasan untuk membeli, Menciptakan sikap atau perasaan positif, Memberikan landasan bagi perluasan. Brand association yang kuat memiliki kesan positif bagi konsumen yang memakainya. Semakin tinggi brand association maka semakin tinggi pula niat beli bagi konsumen (purchase intention). Oleh karena itu, brand association berpengaruh terhadap purchase intention bagi konsumen yang akan memberli suatu produk. Wowor dkk (2014) menjelaskan bahwa brand association yang kuat memiliki kesan positif bagi konsumen yang memakainya.

\section{$\mathrm{H}_{1}$ : Brand association berpengaruh terhadap purchase intention}

\section{Brand Awareness}

Brand awareness adalah kondisi dimana konsumen mampu mengenali produk berdasarkan brand tertentu (Aaker, 1996). Apabila perusahaan memiliki brand awareness yang kuat, maka akan ada tiga keuntungan yang didapatkan (Kotler, 2008) yaitu Learning adventages, Consideration adventages, Choices adventages. Valdo dan Subagio (2017) mengemukakan bahwa brand awareness mempengaruhi minat konsumen untuk membeli suatu produk. Kecenderungan konsumen membeli suatu produk berdasarkan brand yang mereka ketahui. Semakin konsumen mengenali suatu brand, maka hal itu menjadi keunggulan kompetitif bagi suatu produk yang pada akhirnya akan membuat konsumen mau membeli produk tersebut.

\section{H2: Brand awareness berpengaruh terhadap purchase intention}

\section{Price (Harga)}

Harga merupakan jumlah nilai yang dibebankan kepada konsumen untuk untuk dibeli (Kotler, 2002). Harga dari sisi perusahaan merupakan strategi yang sangat jitu untuk merebut perhatian konsumen yang berdampak pada peningkatan penjualan (Hunt et. al, 2015). Namun bagi konsumen, harga juga tidak kalah penting. Konsumen sering menilai nilai suatu barang berdasarkan harga yang dibebankannya. Bagi konsumen, harga yang mahal merupakan cerminan dari kualitas yang tinggi (Tjiptono, 2001). Konsumen akan merasa puas apabila manfaat yang diberikan sesuai dengan harga yang ditawarkan. Namun konsumen juga merasa tidak puas apabila harga tidak sesuai dengan manfaat yang dirasakan oleh konsumen. Wowor dkk (2014) mengemukakan bahwa harga berpengaruh terhadap keinginan membeli oleh konsumen. Hal ini menunjukkan bahwa harga yang sesuai dengan ekspektasi konsumen akan membuat konsumen puas dan berniat untuk membeli.

\section{$\mathrm{H}_{3}$ : Price berpengaruh terhadap purchase intention}

\section{Role Model}

Peran role model tidak hanya sebagai media promosi bagi perusahaan untuk mengenalkan brand mereka. Lebih jauh, kehadiran role model juga sebagai media untuk menyampaikan apa yang menjadi value bagi sebuah brand. Role model didefinisikan sebagai seseorang yang 
dijadikan inspirasi bagi orang lain baik perilaku, atau kesuksesannya (Wikipedia.org). Role model dapat berupa selebriti yaitu seseorang yang mencapai ketenaran pada bidang tertentu. Selebriti yang dimaksud dapat mencakup actor, sport person, politisi, atau pop icon (Run, Butt, Nee, 2010).

Selebriti dianggap mampu mempengaruhi orang lain khususnya remaja dan dewasa untuk mengikuti gaya hidup mereka. Sport star merupakan selebriti yang banyak diidolakan oleh kalangan remaja dan dewasa (Bush dan Martin, 2010). Riset terdahulu menunjukkan bahwa role model memiliki pengaruh yang kuat bagi konsumen dalam membantuk brand yang positif dan kuat (Run, et.al, 2010). Berdasarkan uraian tersebut,maka dapat disimpulkan bahwa:

\section{$\mathrm{H}_{4}$ : Role Model berpengaruh terhadap purchase intention}

\section{METODE PENELITIAN}

\section{a. Populasi, Sampel dan Metode Pengambilan Sampel}

Populasi dalam penelitian ini adalah seluruh masyarakat yang berdomisili di kota Solo, sedangkan sampel dalam penelitian ini adalah 70 masyarakat yang berdomisili dikota Solo. Pada penelitian ini teknik pengambilan sampel menggunakan metode convenience sampling yaitu sampel dari elemen populasi yang datanya mudah diperoleh yaitu dengan cara memilih responden berdasarkan kesediaan responden untuk mengisi kuesioner secara lengkap (Indriantoro, 2002:130).

\section{b. Jenis dan Sumber Data}

Data yang digunakan dalam penelitian ini adalah data primer. Data primer dalam penelitian ini diperoleh dengan cara membagikan kuesioner kepada responden yang menjadi sampel dalam penelitian ini. Kuesioner merupakan teknik pengumpulan data yang dilakukan dengan cara memberi seperangkat pertanyaan atau pernyataan tertulis kepada responden untuk dijawab (Sugiyono, 2014:142), yaitu 150 masyarakat yang berdomisili di kota Solo. Kuesioner yang dibagikan kepada responden berisi pertanyaan-pertanyaan mengenai price, brand association, brand awareness, role model dan purchase intention yang menjadi veriabel delam penelitian ini.

\section{c. Definisi Operasional dan Pengukuran Variabel}

Definisi operasional merupakan unsur penelitian yang memberitahukan bagaimana mengukur suatu variable sehingga dengan pengukuran tersebut dapat diketahui indicator indicator apa saja sebagai pendukung untuk dianalisis ke dalam variable variable tersebut. Variabel dependen dalam penelitian ini adalah Purchase Intention sedangkan variabel independen dalam penelitian ini adalah Brand Association, Brand Awareness, Price, Rule Model. Definisi operasional adalah sebagai berikut:

Tabel 1 Definisi Operasional

\begin{tabular}{|c|c|c|c|}
\hline Variabel & Definisi & Indikator & Sumber \\
\hline $\begin{array}{l}\mathrm{Y} \\
\text { Purchase } \\
\text { Intention }\end{array}$ & $\begin{array}{l}\text { Seberapa } r \text { besar } \\
\text { keinginan konsumen } \\
\text { membeli suatu merek } \\
\text { atau seberapa besar } \\
\text { kemungkinan konsumen } \\
\text { untuk berpindah dari } \\
\text { satu merek ke merek } \\
\text { lainnya }\end{array}$ & $\begin{array}{l}\text { 1. Saya selalu mencari tahu tentang } \\
\text { informasi promo produk } \\
\text { 2. Kebutuhan saya akan olahraga } \\
\text { mendorong saya untuk berniat } \\
\text { membeli produk } \\
\text { 3. Saya tertarik dengan harga yang } \\
\text { ditawarkan } \\
\text { 4. Saya berniat membeli produk }\end{array}$ & $\begin{array}{l}\text { Wowor dan } \\
\text { Lunarjanto } \\
\text { (2014), Run } \\
\text { et al. (2010) }\end{array}$ \\
\hline $\begin{array}{c}\mathrm{X} 1 \\
\text { Brand } \\
\text { Association }\end{array}$ & $\begin{array}{l}\text { Kesan yang ditimbulkan } \\
\text { suatu brand dalam } \\
\text { piikiran seseorang }\end{array}$ & $\begin{array}{l}\text { 1. Brand memiliki ciri khas } \\
\text { 2. Produk mudah diperoleh } \\
\text { 3. Brand lebih baik dari brand lainnya }\end{array}$ & $\begin{array}{c}\text { Wowor dan } \\
\text { Lunarjanto } \\
(2014)\end{array}$ \\
\hline
\end{tabular}




\begin{tabular}{|c|c|c|c|}
\hline & & $\begin{array}{l}\text { 4. Brand mampu bersaing dengan } \\
\text { brand lain }\end{array}$ & \\
\hline $\begin{array}{c}\mathrm{X} 2 \\
\text { Brand } \\
\text { Awareness }\end{array}$ & $\begin{array}{l}\text { Kesanggupan konsumen } \\
\text { untuk mengenali brand }\end{array}$ & $\begin{array}{l}\text { 1. Saya familiar dengan brand produk } \\
\text { 2. Saya sering mendengar tentang } \\
\text { brand produk } \\
\text { 3. Produk terngiang di pikiran saya }\end{array}$ & $\begin{array}{c}\text { Wowor dan } \\
\text { Lunarjanto } \\
\text { (2014) } \\
\text { Wijaya } \\
(2013)\end{array}$ \\
\hline $\begin{array}{c}\text { X3 } \\
\text { Price }\end{array}$ & $\begin{array}{l}\text { Jumlah yang dibebankan } \\
\text { untuk sebuah produk }\end{array}$ & $\begin{array}{l}\text { 1. Harga yang ditawarkan sesuai } \\
\text { dengan manfaat yang diterima } \\
\text { 2. Saya sering membandingkan harga } \\
\text { brand ini dengan brand yang lain } \\
\text { 3. Harga yang ditawarkan bersaing } \\
\text { dengan brand lain } \\
\text { 4. Harga produk sangat menarik }\end{array}$ & $\begin{array}{l}\text { Wowor dan } \\
\text { Lunarjanto } \\
\quad(2014)\end{array}$ \\
\hline $\begin{array}{c}\mathrm{X} 4 \\
\text { Role Model }\end{array}$ & $\begin{array}{l}\text { seseorang yang } \\
\text { dijadikan inspirasi bagi } \\
\text { orang lain baik perilaku, } \\
\text { atau kesuksesannya }\end{array}$ & $\begin{array}{l}\text { 1. Merupakan model yang baik untuk } \\
\text { aku ikuti } \\
\text { 2. Memberikan contoh yang baik } \\
\text { 3. Menyampaikan kesan yang baik } \\
\text { untuk diikuti } \\
\text { 4. Menginspirasi saya untuk saya tiru } \\
\text { 5. Bertindak sebagai role model bagi } \\
\text { saya }\end{array}$ & $\begin{array}{l}\text { Run et. al } \\
\quad(2010\end{array}$ \\
\hline
\end{tabular}

Sumber: Berbagai jurnal

\section{Metode Analisis Data}

Analisis yang digunakan adalah Analisis Regresi Linier Berganda. Analisis ini digunakan untuk mengetahui pengaruh lebih dari satu variabel independen terhadap variabel dependen. Model persamaan regresi untuk menguji hipotesis dengan formulasi sebagai berikut :

$$
\begin{aligned}
& \mathbf{P I}=\alpha+\beta_{1} \mathbf{B A S}+\beta_{2} \mathbf{B A W}+\beta_{3} \mathbf{P R}+\beta_{4} \mathbf{R M}+\mathrm{e} \\
& \text { Keterangan : } \\
& \text { PI } \\
& \text { : Purchase Intention } \\
& \alpha \quad \text { : Konstanta } \\
& \beta_{1}-\beta_{4} \quad \text { : Koefesien regresi } \\
& \text { BAS : Brand Association } \\
& \text { BAW : Brand Awareness } \\
& \text { PR : Price } \\
& \text { RM : Role Model } \\
& \text { e : Error }
\end{aligned}
$$

\section{HASIL DAN PEMBAHASAN}

Data yang digunakan dalam penelitian ini berasal dari kuesioner yang sebarkan kepada masyarakat yang berdomisili di Kota Surakarta. Sampel dalam penelitian dini adalah sebanyak 79 responden. Pemilihan sempel dalam penelitian ini ditentukan dengan metode convenience sampling yaitu sampel dari elemen populasi yang datanya mudah diperoleh yaitu dengan cara memilih responden berdasarkan kesediaan responden untuk mengisi kuesioner secara lengkap (Indriantoro, 2002:130). 


\section{Hasil Penelitian \\ Uji Kulaitas Data \\ Uji Validitas}

Hasil uji validitas seluruh item intrumen pertanyaan kuesioner pada seluruh variabel dalam penelitian ini memperoleh nilai r-hitung > r-tabel. Hal ini menunjukkan bahwa seluruh item instrumen pertanyaan kuesioner pada seluruh varibel dalam penelitian ini valid sehingga dapat digunakan sebagai alat ukur variabel.

\section{Uji Reliabilitas}

Hasil uji Reliabilitas seluruh variabel dalam penelitian ini memperoleh nilai Cronbach's Alpha $>$ 0,6. Hal ini menunjukkan bahwa seluruh bahwa pertanyaan yang digunakan dalam intrumen variabel adalah reliabel atau handal untuk digunakan sebagai alat ukur variabel.

\section{Uji Asumsi Klasik}

\section{Uji Normalitas}

Uji normalitas bertujuan untuk menguji apakah dalam model regresi, variabel pengganggu atau residual memiliki distribusi normal. Seperti diketahui bahwa uji t dan F mengasumsikan bahwa nilai residual mengikuti distribusi normal.

Tabel 2 Hasil Uji Normalitas Data

\begin{tabular}{lr}
\multicolumn{1}{c}{ Keterangan } & $\begin{array}{c}\text { Unstandardized } \\
\text { Residual }\end{array}$ \\
\hline Kolmogorov-Smirnov Z & 0,672 \\
Asymp. Sig. (2-tailed) & 0,757 \\
\hline
\end{tabular}

Sumber: Data sekunder yang diolah, 2016.

Pada tabel 4.3 tersebut menunjukkan hasil perhitungan Kolmogorov-Smirnov diperoleh nilai signifikansi 0,757 sehingga semua variabel diketahui lebih besar dari $\alpha(p>0,05)$, maka dapat dinyatakan data residual berdistribusi normal atau seluruh data memiliki sebaran data normal.

\section{Uji Multikolinearitas}

Uji multikolonieritas bertujuan untuk menguji apakah model regresi ditemukan adanya korelasi antar variabel bebas (independen). Dari hasil uji multikolinieritas menunjukan bahwa semua variabel independen memiliki nilai tolerance lebih dari $0,1(10 \%)$ dan hasil perhitungan juga menunjukan bahwa semua variabel bebas memiliki VIF kurang dari 10 (VIF<10), artinya tidak ada kolerasi antar variabel bebas. Jadi dapat disimpulkan tidak ada gejala multikolinieritas dalam model regresi yang digunakan.

Tabel 4.2

Hasil Uji Multikolinearitas

\begin{tabular}{llll}
\hline Variabel & Tolerance & $\boldsymbol{V I F}$ & Keterangan \\
\hline BAW & 0,548 & 1,824 & Tidak terjadi multikolinearitas \\
BAS & 0,471 & 2,121 & Tidak terjadi multikolinearitas \\
PR & 0,539 & 1,855 & Tidak terjadi multikolinearitas \\
RM & 0,795 & 1,258 & Tidak terjadi multikolinearitas \\
\hline
\end{tabular}

Sumber: Data primer diolah, 2019 


\section{Uji Heteroskedastisitas}

Uji heteroskedastisitas bertujuan untuk menguji apakah dalam model regresi terjadi ketidaksamaan variance dari residual satu pengamatan ke pengamatan yang lain. Dari hasil perhitungan menunjukan tidak ada gangguan heteroskedastisitas yang terjadi dalam proses estimasi parameter model penduga, dimana tidak ada $p$-value kurang dari 0,05. Jadi secara keseluruhan dapat disimpulkan bahwa tidak ada masalah heteroskedastisitas dalam penelitian ini.

Tabel 3 Hasil Uji Heterokedastisitas

\begin{tabular}{lcc}
\hline Variabel & p-value & Keterangan \\
\hline BAS & 0,651 & Tidak terjadi heteroskedastisitas \\
BAW & 0,901 & Tidak terjadi heteroskedastisitas \\
PR & 0,406 & Tidak terjadi heteroskedastisitas \\
RM & 0,799 & Tidak terjadi heteroskedastisitas \\
\hline
\end{tabular}

Sumber: Data yang diolah, 2019

Berdasarkan uji asumsi klasik (normalitas, autokolerasi, multikolinearitas, heteroskedastisitas) diperoleh bahwa model yang digunakan tidak terjadi penyimpangan asumsi klasik, artinya model regresi pada penelitian ini dapat digunakan sebagai dasar analisis.

\section{Analisis Regresi Linear Berganda}

Analisi data yang digunakan dalam penelitian ini yaitu analisis regresi berganda dengan metode Ordinary Least Square (OLS). Inti metode OLS adalah mengestimasi suatu garis regresi dengan jalan meminimalkan jumlah dari kuadrat kesalahan setiap observasi terhadap garis tersebut. (Ghozali, 2011:96). Analisis regresi berganda digunakan untuk mengetahui pengaruh Brand Association, Brand Awareness, Price dan Role Model terhadap Purchase Intention. Hasil analisi regresi berganda adalah sebagai berikut :

Tabel 4. Hasil Uji Regresi Berganda

\begin{tabular}{l|l|l|l|l}
\hline Variabel & Koefisien & t-hitung & Sig. & Keterangan \\
\hline (Constant) & $-2,804$ & & & \\
BAS & $-0,054$ & $-0,267$ & 0,790 & Tidak Berpengaruh \\
BAW & 0,201 & 1,124 & 0,265 & Tidak Berpengaruh \\
PR & 0,761 & 4,428 & 0,000 & Berpengaruh \\
RM & 0,182 & 2,147 & 0,035 & Berpengaruh \\
\hline F-hitung & 16,112 & & \\
Probabilitas & 0,000 & & \\
Adjusted R2 & 0,437 & & \\
\hline
\end{tabular}

Sumber: Data primer diolah, 2019.

Berdasarkan tabel 4 diatas, maka diperoleh persamaan regresi sebagai berikut:

$$
\mathrm{PI}=-2,804-0,054 \mathrm{BAS}+0,201 \mathrm{BAW}+0,761 \mathrm{PR}+0,182 \mathrm{RM}+\varepsilon
$$




\section{Hasil Uji Signifikansi Simultan (Uji F)}

Hasil uji statistik $F$ pada tabel diatas menunjukkan bahwa $F_{\text {hitung }}$ sebesar 16,112 dengan angka signifikan $0,000<0,05$, sehingga dapat disimpulkan bahwa model penelitian ini adalah fit dengan kata lain menunjukkan bahwa seluruh variabel independen yaitu Brand Association, Brand Awareness, Price dan Role Model berpengaruh terhadap Purchase Intention.

\section{Uji Koefisien Determinasi $\left(\mathbf{R}^{2}\right)$}

Berdasarkan hasil uji koefisien determinasi $\left(\mathrm{R}^{2}\right)$ pada tabel diatas menunjukkan besarnya adjusted $\mathrm{R}^{2}$ adalah 0,437 . Hal ini berarti bahwa variabel yang mempengaruhi Purchase Intention dapat dijelaskan oleh variabel Brand Association, Brand Awareness, Price dan Role Model dalam model persamaan ini adalah sebesar $43,7 \%$ sedangkan sisanya $56,3 \%$ dipengaruhi oleh faktor lain yang tidak dimasukkan dalam model regresi.

\section{Pembasahan}

\section{a. Hipotesis 1 (Brand association berpengaruh terhadap purchase intention)}

Berdasarkan hasil penelitian pada variabel Brand Association dalam pengujian hipotesis pertama diperoleh nilai signifikansi lebih dari $0,05(0,790>0,05)$. Hal ini berarti bahwa H1 ditolak, sehingga menunjukan bahwa Brand Association tidak berpengaruh terhadap purchase intention. Hal ini dikarenakan para konsumen tidak melihat merek papan atas atau brand association, melainkan konsumen lebih memperhatikan kulitas dan harga yang terjangkau. Beredarnya barang-barang tiruan yang hampir sama dengan model-model papan atas dapat meragukan konsumen untuk membeli barang merek papan atas yang harganya tinggi. Banyaknya barang-barang tiruan dapat menurunkan kebanggaan dalam memakai merek papan atas dikarenakan bahwa orang lain menganggap apa yang digunakan oleh konsumen tersebuat hanyalah barang tiruan walaupun itu memang barang aslinya.

\section{b. Hipotesis 2 (Brand awareness berpengaruh terhadap purchase intention)}

Berdasarkan hasil penelitian pada variabel Brand Awareness dalam pengujian hipotesis kedua diperoleh nilai signifikansi lebih besar dari $0,05(0,265>0,05)$. Hal ini berarti bahwa $\mathrm{H} 2$ ditolak, sehingga menunjukan bahwa Brand Awareness tidak berpengaruh terhadap purchase intention. Brand awareness adalah kondisi dimana konsumen mampu mengenali produk berdasarkan brand tertentu (Aaker, 1996). Perkembangan teknologi yang sangat pesat membuat para konsumen dapat memperoleh informasi mengenaik suatu produk dengan cepat. Mudahnya memperoleh informasi dapat membuat para konsumen mengetahui kekurangan dan kelemahan suatu produk. Hal ini menyebabkan para konsumen ragu dalam membeli produk tersebut. Sehingga brand awareness tidak berpengaruh terhadap Purchase Intention

\section{c. Hipotesis 3 (Price berpengaruh terhadap purchase intention)}

Berdasarkan hasil penelitian pada variabel Price dalam pengujian hipotesis ketiga diperoleh tingkat signifikansi kurang dari $0,05(0,000<0,05)$. Hal ini berarti $\mathrm{H}_{3}$ diterima, menunjukan bahwa Price berpengaruh signifikan terhadap purchase intention. Harga suatu produk merupakan factor yang sangat diperhatikan oleh konsumen. Harga dari sisi perusahaan merupakan strategi yang sangat jitu untuk merebut perhatian konsumen yang berdampak pada peningkatan penjualan (Hunt et. al, 2015). Konsumen sering menilai suatu barang berdasarkan harga yang dibebankannya. Bagi konsumen, harga yang mahal merupakan cerminan dari kualitas yang tinggi (Tjiptono, 2001). Konsumen akan merasa puas apabila manfaat yang diberikan sesuai dengan harga yang ditawarkan. Namun konsumen juga merasa tidak puas apabila harga tidak sesuai dengan manfaat yang dirasakan oleh konsumen. Wowor dkk (2014) mengemukakan 
bahwa harga berpengaruh terhadap keinginan membeli oleh konsumen. Hal ini menunjukkan bahwa harga yang sesuai dengan ekspektasi konsumen akan membuat konsumen puas dan berniat untuk membeli. Hasil penelitian ini sejalan dengan hasil penelitian Wowor dan Lunarjanto (2014) yang menjelaskan bahwa harga mempengaruhi konsumen untuk membeli tiket pesawat Garuda Indonesia.

\section{d. Hipotesis 4 (Role Model berpengaruh terhadap purchase intention)}

Berdasarkan hasil penelitian pada variabel Role Model dalam pengujian hipotesis keempat diperoleh nilai signifikansi kurang dari $0,05 \quad(0,035<0,05)$. Hal ini berarti $\mathrm{H}_{4}$ diterima, menunjukan bahwa Role Model berpengaruh signifikan terhadap purchase intention. Role model merupakan media promosi untuk mengenalkan dan menyampaikan apa yang menjadi value bagi sebuah brand. Role model didefinisikan sebagai seseorang yang dijadikan inspirasi bagi orang lain baik perilaku, atau kesuksesannya (Wikipedia.org). Role model dapat berupa selebriti yaitu seseorang yang mencapai ketenaran pada bidang tertentu. Selebriti memapu mempengaruhi konsumen untuk mengikuti gaya hidup mereka. Konsumen merasa bangga apabila bisa mengikuti gaya hidup para selebriti. Sport star merupakan selebriti yang banyak diidolakan oleh kalangan remaja dan dewasa (Bush dan Martin, 2010). Penggunaan sepatu Nike yang sering digunakan dan dipromosikan oleh pemain sepak bola yang terkenal dapat membuat para penggemarnya tertarik untuk membeli sepatu Nike. Riset terdahulu menunjukkan bahwa role model memiliki pengaruh yang kuat bagi konsumen dalam membantuk brand yang positif dan kuat (Run, et.al, 2010). Hasil penelitian ini sejalan dengan hasil penelitian Haroon, Haq, Najmo (2015) yang menyatakan bahwa Role Model berpengaruh terhadap Purchase Intention .

\section{SIMPULAN \\ Simpulan}

Berdasarkan hasil analisis data dan pembahasan hasil penelitian mengenai pengaruh Brand Association, Brand Awareness, Price dan Role Model terhadap Purchase Intention maka dapat ditarik kesimpulan bahwa Association, Brand Awareness tidak berpengaruh terhadap Purchase Intention dan Price dan Role Model berpengaruh terhadap Purchase Intention.

\section{Implikasi}

1) Penelitian ini dapat digunakan sebagai alat bantu analisis strategi pemasaran untuk penjualan suatu produk agar dapat memberikan dampak positif bagi perusahaan dan wirausaha.

2) Penelitian ini dapat digunakan untuk menambah pengetahuan intelektual serta mampu meningkatkan pemahaman terkait dengan faktor-faktor yang mempengaruhi Purchase Intention.

\section{Keterbatasan Penelitian}

Dalam penelitian ini terdapat beberapa keterbatasan penelitian yang perlu dipertimbangkan yang mungkin mempengaruhi hasil penelitian. Adapun keterbatasan dalam penelitian ini antara lain:

1) Penelitian ini hanya menggunakan 4 variabel independen saja, yaitu Brand Association, Brand Awareness, Price dan Role Model.

2) Objek yang digunakan dalam penelitian ini hanyalah konsumen yang berdomisili di Kota Surakarta saja. Sehingga hasilnya belum mencakup seluruh konsumen yang ada di Indonesia.

3) Jumlah sampel dalam penelitian ini hanyalah 79 sampel. 


\section{Saran}

Berdasarkan keterbatasan yang diambil dalam penelitian ini, maka penulis memberikan saran sebagai berikut:

1) Penelitian selanjutnya diharapkan untuk memperluas cakupan penelitiannya, dimana menggunakan variabel-variabel lain selain Brand Association, Brand Awareness, Price dan Role Model.

2) Penelitian selanjutnya diharapkan memperluas objek penelitian di Jawa atau Indonesia.

3) Penelitian selanjutnya diharapkan dapat menggunakan sampel data yang lebih banyak.

\section{DAFTAR PUSTAKA}

Aaker, D. A. (1996). Building Strong Brands. New York: Free Press.

Assael, H. (1998). Consumer Behaviour and Marketing Action. America: New York University.

Bush, A. J., \& Martin, C.A. (2000). Do Role Models Influence Teenager's Purchase Intention and Behaviour?. Journal of Consumer Marketing. Vol. 17 (5). 441 -

Durianto, Sugiarto \& Sitinjak. (2001). Strategi Menaklukan Pasar Melalui Riset Merek. Jakarta: Gramedia

Ferdinand, A. (2006). Metode Penelitian Manajemen: Pedoman Penelitian untuk

Penulisan Skripsi, Tesis, dan Disertasi Ilmu Manajemen. Semarang: Badan Penerbit Universitas Diponegoro.

Ghozal, Imam. (2006). Aplikasi Analisis Multivariate dengan Program SPSS. Semarang: Universitas Diponegoro

Ghozal, Imam. (2011). Aplikasi Analisis Multivariate dengan Program IBM SPSS Semarang: Universitas Diponegoro

Ghozal, Imam. (2012). Aplikasi Analisis Multivariate dengan Program IBM SPSS. Semarang: Universitas Diponegoro

Haroo, M.Z, Haq, M,A. Najmonnisa (2015). Impact Of Role Model On Behavioral And Purchase Intetion Among Youngster: Empirical Studi From Karachi, Pakistan. Journal of Management Sciences. Vol 2 (2). 243 - 255.

Hunt C,S. dan Mello J.E. (2015). Marketing. Boston: Mc Graw Hill. Indriantoro, Nur, \& Supomo, Bambang. (2014). Metodologi Penelitian Bisnis Untuk Akuntansi \& Manajemen. Yogyakarta. BPFE-Yogyakarta

Kotler \& Keller (2006). Marketing Management, 12th Edition. New Jersey: Prentice Hall

Kotler \& Keller (2008). Manajemen Pemasaran. Jakarta: Index

Kotler, N. \& Kotler, P. (1998). Museum Strategy and Marketing. San Francisco: Jossey - Bass A Willey Imprint

Kotler \& Keller (2006). Marketing Management 12th Edition. New Jersey: Prentice Hall. 
Nikisusastro, M. (2012). Perilaku Konsumen dalam Perspektif Perusahaan. Bandung: Alfabeta.

Run, E,C, Butt, M., Nee, C. Y. (2010). The Influence of Role Model on Young Adult Purchase. Jurnal Kemanusiaan.

Sugiyono (2012). Metode Penelitian Kuantitatif, Kualitatif dan R \& D. Bandung: Alfabetha

Sugiyono (2014). Metode Penelitian Pendidikan Pendekatan Kuantitatif, Kualitatif dan R \& D. Bandung: Alfabetha.

Tjiptono \& Fandy (2005). Service Quality and Satisfaction. Yogyakarta: Andi Offset.

Valdo, J. \& Subagio, H. (2017). Analisis Pengaruh Brand Equity tehadap Purchase Intention kepada Konsumen pada Produk PC Tablet Apple Ipad di Surabaya. Jurnal Strategi Pemasaran. No. 2 (4).

Widarjono, Agus. (2010). Analisis Statistika Multivariat Terapan. Edisi Pertama. Yogyakarta UPP STIM YKPN

Wowor S. \& Lunarjanto A. (2014). Pengaruh Brand Equity dan Pricing terhadap

Purchase Intention Markapai Low Cost Carrier di Jakarta. Journal of Business Strategy and Execution. No 7 (1). $45-81$.

www.wikipedia.org diakses 26 Januari 2019 